Intersections

Canadian Journal of Music

Revue canadienne de musique
Intersections CANADIAN JOURAL OF MUSIC

\title{
Madness in Linda Bouchard's Black Burned Wood
}

\section{Kirsten Yri}

Volume 29, numéro 1, 2009

URI : https://id.erudit.org/iderudit/039110ar

DOI : https://doi.org/10.7202/039110ar

Aller au sommaire du numéro

\section{Éditeur(s)}

Canadian University Music Society / Société de musique des universités canadiennes

ISSN

1911-0146 (imprimé)

1918-512X (numérique)

Découvrir la revue

Citer cet article

Yri, K. (2009). Madness in Linda Bouchard's Black Burned Wood. Intersections, 29(1), 49-69. https://doi.org/10.7202/039110ar

\section{Résumé de l'article}

Par ses images de paranoïa, de colère, de sacrifice et d'infantilisme, Black Burned Wood de Linda Bouchard peut facilement s'inscrire dans le sillage des représentations musicales de la folie féminine. Le livret, un cycle de 11 poèmes réunis sous le titre de "Sara Songs ", prend la forme d'un monologue décousu dans lequel le personnage de Sara peine à accepter son rôle dans un acte incertain mais horrible. Bien que la structure syntaxique et le phrasé des poèmes montrent le déséquilibre mental de Sara, c'est la musique qui est responsable de la description instantanée et incroyablement à vif de sa folie. Cet article explore l'utilisation de la fragmentation, de la non-linéarité, de la fixation musicale et de la dissonance pour représenter musicalement la folie de Sara.
Tous droits réservés (C) Canadian University Music Society / Société de musique des universités canadiennes, 2009
Ce document est protégé par la loi sur le droit d'auteur. L'utilisation des services d'Érudit (y compris la reproduction) est assujettie à sa politique d'utilisation que vous pouvez consulter en ligne.

https://apropos.erudit.org/fr/usagers/politique-dutilisation/ 


\title{
MADNESS IN LINDA BOUCHARD'S BLACK BURNED WOOD
}

\author{
Kirsten Yri
}

The haunting resonance of temple gongs suffused by low rumbling, a foreboding demon brooding, hidden. A demented glissando transformed by a wash of chimes. Dreams. Nursery rhymes wickedly tinkled out on a piano. Nightmares, creaking floorboards, the sound of stalking footsteps, ever closer. So characterize the sounds and images of terror Sara struggles to repress in Linda Bouchard's 1990 song cycle, Black Burned Wood. "No!" her shrieks echo hysterically, "Don't let it be!" But as her hysteria subsides into an eerily subdued reliving of childhood, it becomes increasingly clear that Sara's experience is no ordinary nightmare; it is her reality, a demented and deranged one.

With these-the images of hysteria, paranoia, and dementia-Black Burned Wood may easily be aligned with musical representations of madwomen. The text, a cycle of eleven poems collected under the title "Sara Songs" written by John O'Keefe, takes the form of a rambling monologue in which Sara struggles to come to grips with an unspecified but horrible act. ${ }^{1}$ Her emotional responses, fluctuating wildly between anger, disbelief, resignation, repression, and denial, specifically suggest she suffers from a psychological illness resembling nineteenth-century representations of madness. ${ }^{2}$ The musical setting, scored for instrumental combinations drawn from voice, violin, viola, piano, marimba, xylophone, drum set, and percussion by Canadian Linda Bouchard (b. 1957), is written to depict the physical manifestations of these states of madness, in some cases constructing mimetic representations of Sara's emotional states. As in other works that feature mad characters, the line between what is "real" or what is "not real" is difficult to draw and listeners cannot be certain whether Sara is "really" responding to something she has done, or whether she has imagined the whole episode.

The circumstances behind the composition also provide a context for understanding Black Burned Wood within a genre of representations of madwomen. The piece was one of the five works commissioned by soprano Dora Ohrenstein for her project Urban Diva (premiered in 1990, and released by CRI in 1993), which presents, as the title suggests, a modern setting for the dramatic expression of the "diva." Each of the five pieces for the project centres on a

1 The author suggests that Sara may have killed her parents. Liner notes, Dora Ohrenstein, The Urban Diva, CRi CD 654.

2 For literature on madness, see Phyllis Chesler, Women and Madness (New York: Four Walls Eight Windows, 1988); Michel Foucault, Madness and Civilization: A History of Insanity in the Age of Reason, trans. Richard Howard (New York: Vintage Books, 1988); Elaine Showalter, The Female Malady: Women, Madness, and English Culture 1830-1980 (New York: Pantheon Books, 1985); and Jane Ussher, Women's Madness: Misogyny or Mental Illness? (Amherst: University of Massachusetts Press, 1992). 
female protagonist and her wild or erratic responses within a given narrative. Each character misbehaves (as divas are reputed to do) and each exhibits unconventional behaviour, projecting extremes of sorrow, anger, or bouts of fantasy or hysteria. ${ }^{3}$ In short, the project's content sustains the image of the diva's "demented" state, in keeping with one of the alluring features for opera fans described by Ethan Morrden in his book Demented: The World of the Opera Diva. 4

This paper discusses the musical techniques Bouchard uses to communicate Sara's demise-establishing and then breaking large-scale formal structures, musical fixation, and dissonant musical syntax-and situates them against historical representations of madwomen. The tendency in musicological scholarship on madness has been to focus on opera where the character's hysteria is "framed" by the normative musical language of the other characters. 5 As Susan McClary argues, "Normative procedures representing reason are erected around them [madwomen] to serve as protective frames preventing "contagion." 6 Whether these procedures take the form of harmonic constraints, musical syntax, or plot, they establish the musical context that determines what is musically acceptable and what is abnormal. But in a work of this nature there are no other characters to contrast or frame the musical utterances of Sara. Nor is there a plot to illustrate the social consequences of Sara's madness. The spectacle of the mad diva has not disappeared, however; it is simply that she is now the subject of the audience's gaze, and the frame is erected between the normative language of the audience and the madwoman's ravings. The idea of "normative language" may appear to be problematic in an era of postmodernity where compositional language is more musically and stylistically diverse than ever before, yet Bouchard's musical language relies on specific musical nuances and large-scale compositional strategies that have historically been used to frame mad characters. While I acknowledge that there is a vastly different cultural context and musical surface in works from the past such as Monteverdi's Lamento della Ninfa, or Donizetti's Lucia di Lammermoor, among others, their statements of madness are communicated primarily through the inherited codes or musical techniques I explore.

The syntactic structure of O'Keefe's poem is consistent with discursive representations of madwomen and constructs Sara's madness by inherited codes or techniques. As scholars have discussed, these techniques often include

3 Ohrenstein is vague about the link of these pieces to an intended representation of madness, but it is evident from the liner notes that she is aware of the character's wild behaviour.

4 Ethan Morrden, Demented: The World of the Opera Diva (New York: Franklin Watts, 1984).

5 For literature on madness in music, see Catherine Clément, Opera or the Undoing of Women, trans. Betsy Wing (Minneapolis: University of Minnesota Press, 1988); Susan McClary, "Excess and Frame: The Musical Representation of Madwomen," in Feminine Endings, Music, Gender, and Sexuality, 80-111 (Minnesota: University of Minnesota Press, 1991); Ellen Rosand, "Operatic Madness, A Challenge to Convention," in Music and Text: Critical Inquiries, ed. Steven Paul Scher, 241-87 (Cambridge: Cambridge University Press, 1992); Mary Ann Smart, "The Silencing of Lucia," Cambridge Opera Journal 4, no. 2 (1992): 119-41; Alan E. Williams, "Madness in the Music Theater Works of Peter Maxwell Davies," Perspectives of New Music 38, no. 1 (2000): 77-100.

6 McClary, Feminine Endings, 81. 
deviations in verbal logic, strategies of fragmentation, and a divergence from linearity. In her work on madness in early modern culture, for instance, Carol Thomas Neely notes, "Shakespeare's language of madness is characterized by fragmentation, obsession, and repetition, and most importantly, by [what I will call] 'quotation,"'7 the same techniques used in the poetic texts by O'Keefe. Indeed, as with Ophelia before her, Sara's loss of control, caused by an awareness of reality, is evident in the fragmentation and relentlessness of the text. Also similar to Ophelia and other mad characters, Sara finds refuge from her troubles in nature; her mind is drawn to the forest where nature embodies her and she experiences heightened intuition. ${ }^{8}$ Sara's madness is also communicated by her regression to a childlike state. Although there is madness in men's music, as can be seen in Pierrot, Wozzeck, or Eight Songs for a Mad King, it is precisely this childlike state that is important here: on both poetic and musical levels, Sara's female brand of madness is distinguished by her infantilism. Here, O'Keefe and Bouchard appear to be drawing on Charlotte Perkins Gilman's The Yellow Wallpaper, the classic story of a supposed madwoman locked up in a children's nursery by her paternalistic husband/physician. ${ }^{9}$

Whereas the woman's infantilism is framed by her confinement in the nursery, Sara's is reinforced by her tantrums, her stream-of-consciousness utterances, and her lapses into third-person narrative. Finally, incapable of facing the unnamed act, Sara finds herself, like other mad characters, caught in a world restricted to repetitions of sentence fragments and one-syllable words. But guilt triggers paranoia-she hears voices talking to her, calling her, compelling her to explain her actions.

Though the syntactic structure and verbal content of the poems place Sara in a state of derangement, it is the musical setting that is responsible for the instantaneous and overwhelmingly raw portrayal of her madness. Following historical precedents for the musical representation of madwomen, Bouchard's compositional practices exploit fragmentation, musical fixation, dissonance, and a lack of linearity. In terms of lack of linearity and fragmentation, the composition sets up a structure that communicates disorder, and as such, defines it as part of the dramatic tradition of Ophelia, Lucia, and the Woman in Erwartung, whose freely associative thought processes are typically the terrain of madwomen..$^{10}$ An obsessive cycling of musical events thwarts all hope for linear narrative and parallels stream-of-consciousness expression. This sense of disorder and fragmentation is structured as follows: the eleven stanzas of

7 Carol Thomas Neely, "Documents in Madness': Reading Madness and Gender in Shakespeare's Tragedies and Early Modern Culture," Shakespeare Quarterly 42, no. 3 (1991): 323.

8 As Sandra Gilbert and Susan Gubar explore in nineteenth-century literature by women, concepts of nature are often constructed as female, and as the polar opposite to culture. See The Madwoman in the Attic: The Woman Writer and the Nineteenth Century Literary Imagination (New Haven: Yale University Press, 1979); for more on embodiment, see Katie Conboy, Nadia Medina, and Sarah Stanbury, eds., Writing on the Body: Female Embodiment and Feminist Theory (New York: Columbia University Press, 1997).

9 See especially Showalter, Female Malady, 139-42.

10 See especially Smart, "Silencing of Lucia"; Rosand, "Operatic Madness: and McClary, "Excess and Frame." 
the poem group into three different states of madness on the basis of textual and musical attributes. Bouchard uses similar sounds and musical motives to musically identify each strand with an emotional character. By way of introduction to the three strands of madness and their musical sound worlds, I chart out very basic characteristics of each strand (see figure 1). Strand A musically expresses Sara's hysteria by the use of a dissonant sound world, screaming, shouting, and complex rhythms set to a tempo of quarter note $=120$. Strand B characterizes Sara's regression to a state of childhood by the slower tempo of the strained singing of a familiar children's tune in duple metre. Strand C represents Sara's conflicted self as she faces her role in an unnamed tragedy. The music of this strand is marked by a static accompaniment and a slower-paced, lyrical, but angular and disjointed movement akin to the kind of motion one finds in Schoenberg's expressionist works Erwartung or Pierrot Lunaire.

Figure 1: Characteristics of strands

\begin{tabular}{||l|l|l|l||}
\hline \multicolumn{1}{|c|}{ Strand } & \multicolumn{1}{|c|}{ A (Hysteria) } & \multicolumn{1}{c|}{ B (Regression) } & \multicolumn{1}{c||}{ C (Conflicted self) } \\
\hline Stanzas & $1,3,6,9$ & $2,5,(8), 11$ & $4,7,(8), 10$ \\
\hline Tempo & Fast q = 120 & Slow q $=72$ & Slower q = 66 \\
\hline Aspect & Hysteria & Regression & Schizophrenic \\
\hline Sound world & Dissonant & Familiar tune & Angular \\
\hline Vocal style & Screams, shouts & Strained singing & Disjointed melodies \\
\hline Metric placement & Sporadic, complex & Steady, simple & Static \\
\hline
\end{tabular}

These three different states of madness, labelled A, B, and C, are distributed through the work to capitalize on a juxtaposition of extremes, a recurring theme in representations of madness (see figure 2). The numbers represent the poem's stanzas. The first state of madness (in stanza 1), characterized by blatant hysteria, alternates with the second, a regression to childhood (stanza 2), only to fragment and return to the first (stanza 3) before moving to the third (stanza 4), a tortured conflict where guilt overwhelms Sara to the point of semiconsciousness.

Figure 2: Linear movement of stanzas through strands

\begin{tabular}{|c|l|l|l|l|l|l|l|l|l|l|l||}
\hline State of madness & \multicolumn{10}{|c|}{ Stanza } \\
\hline A & 1 & & 3 & & & 6 & & & 9 & & \\
\hline B & & 2 & & & 5 & & & $8^{*}$ & & & 11 \\
\hline C & & & & 4 & & & 7 & & & 10 & \\
\hline
\end{tabular}

The pattern is perhaps better expressed by figure 3. Here, letters indicate strand and numbers indicate stanza.

As the figure shows, the pattern adopts a cyclical structure wherein all but the first case $\left(\mathrm{A}_{1}-\mathrm{B}_{2}\right)$, stanzas from strand $\mathrm{A}$ move to $\mathrm{C}, \mathrm{C}$ to $\mathrm{B}$, and $\mathrm{B}$ to $\mathrm{A}$. 
Figure 3: $\quad$ Cyclical structure

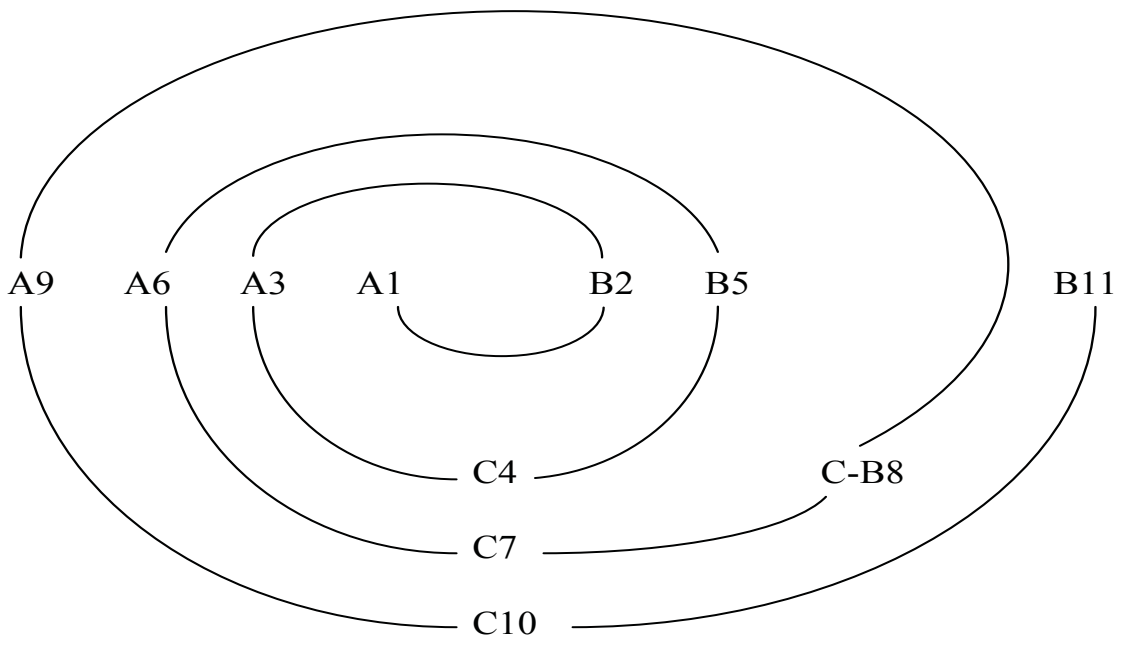

Stanza C-B8 breaks down the distinctions between C and B, its characteristics deriving from both.

This cyclical structure of the succession of strands imposes a return of musical strands at regularly spaced intervals. The circular motion conveyed by these returns stresses the extent to which Sara is doomed to slip back into the states of neurosis defined for her-hysteria, regression to a childlike state, and schizophrenic conflict. The action thus realizes a kind of loop structure wherein the powerful outbursts of hysteria inherent to stanzas of A overwhelm Sara until she falls into a quieter guilt-ridden contemplation of whether to deny or admit her action. This state of conflict in turn sets off strand B's regression in which she represses the event and denies responsibility. But, unsuccessful in repressing her actions, Sara is overwhelmed with guilt and collapses in a state of hysteria-the cycle begins again, for there is no escape from this loop. This continuous alternation and the chronological succession of strands of different musical sound worlds mirror Sara's volatile movement from one extreme emotional state to the next, equating this extreme behaviour with madness.

Sara thus abandons the musical ideas defined for her by musical convention in much the same way as operatic madwomen defy formal expectations. As Mary Ann Smart discusses, in the final scene of Donizetti's Lucia di Lammermoor, where Lucia emerges from the wedding chamber having just murdered her husband, her madness is conveyed by the fragmentations and interruptions of her musical line, interruptions posed by past themes that "mimic Lucia's confused thought processes."11 Similar techniques are evident in the language of Ophelia, whose madness Ellen Rosand describes as "gaining 
credibility by flaunting not only the conventions of behaviour, but those of language as well: by breaking rules of logic with abstruse allusions, incongruous juxtapositions, disconnected exclamations." ${ }^{12}$

Though figure 2 suggests that the succession of the strands is a static enterprise (that is, that each strand is static in characteristics), in fact, as the stanzas cycle from one to the next, the distinctions between two of the strands begin to break down. As is shown in figure 3 , what distinguishes stanza 7 from 8 becomes murky, forcing the latter to be included halfway between the two strands $\mathrm{B}$ and $\mathrm{C}$. This disintegration of the strands' characteristics narrates a similar decay in Sara's inability to cope with her world, and parallels that of Lucia in her mad scene: Lucia's madness is palpable in her inability to follow formal operatic conventions as when she remains rooted in recitative while the orchestra begins the cantabile. ${ }^{13}$

The restricted use of pitch, or musical fixation, is also a sign of Sara's madness in Black Burned Wood. As Ellen Rosand discusses, a restricted use of pitch or a musical setting that isolates and reiterates single words or musical phrases communicates madness by upsetting "conventional discourse." 14 As she discusses, Monteverdi uses musical fixation to symbolize Deidamia's madness in La finta pazza Licori and Iro's irrationality in Il ritorno d'Ulisse in patria. Signs of madness in the form of musical fixation also appear in Monteverdi's Lamento della Ninfa where the ostinato bass underscores the nymph's obsessive quality. Susan McClary describes the nymph as "fixated on memories of a lover who has abandoned her-who has awakened her sexually and has left her with no outlet for that excess, no recourse but madness." 15 As I will discuss shortly, repetition and restricted use of pitch is a feature of Sara's vocal line and the music that accompanies Sara's three different mental states. Musical fixation is also heard in the form of a $\mathrm{D}^{b}-\mathrm{C}$ dyad that gradually intrudes into her vocal line and is ultimately the "musical" reason for her breakdown.

Finally, the use of dissonance, especially in the context of atonal or posttonal music, also has musico-historical precedence in characterizations of madness. It is perhaps here where the structure and syntax of the musical material in Black Burned Wood create the most powerful images and associations for the listener. As McClary contends in her discussion of Strauss's Salome as madwoman, it is by deviating from the normative musical discourse of diatonicism and moving into chromatic excess that Salome seals her fate as a deranged woman. Although atonality is part of the modernist musical discourse, it still appears to be heard against normative musical processes such that it "negates the sense of temporal coherence and unity

12 Rosand, “Operatic Madness," 242.

13 Smart, "Silencing of Lucia," 131. In this case, Smart is discussing the shift from scena to slow movement, as "a deliberate flouting of formal convention."

14 Rosand, "Operatic Madness," 264.

15 McClary, Feminine Endings, 86-7. 
rooted in the principle of tonal closure."16 More importantly, because of the historical prominence of dissonance in atonal works associated with mad characters-Schoenberg's Pierrot Lunaire, Erwartung, Berg's Wozzeck, Strauss's Salome, Boulez's Le Marteau sans Maître, or even Hermann's music for the Hitchcock films Psycho or Vertigo, dissonance still confers on the music the sense of irrationality that goes along with the subject matter of its mad protagonists. Perhaps in order to expand the levels of dissonance in the modernist world of composition where it has become increasingly normative, sounds with violent imagery now provide further recourse to transgression. With its reliance on violence and transgression in the use of voice and the handling of the text, Peter Maxwell Davies' Eight Songs for a Mad King epitomizes the extremes to which composers must go to convey madness in the modernist world of composition. In his article on madness, Alan Williams cites Maxwell Davies' description of the musical sounds produced by violent means, or "sounds made by human beings under extreme duress," as "antimusical"; he also includes in this category the use of sound elements that transgress the boundaries of normative playing techniques for instruments. ${ }^{17}$ In keeping with the kinds of antimusical elements Williams describes, Sara moves beyond the bounds of musical discourse by screaming and shouting. The low snarling slides against light pizzicato, and the sounds of low piano strings being strummed back and forth to an ever-increasing volume also help convey a sinister, eerie atmosphere, being as they are outside normative musical language.

The text-based grouping of stanzas 1, 3, 6, and 9 in strand A is projected through lexical, syntactic, and thematic means. In each poetic stanza in this strand, Sara confronts the tragic events and becomes overwhelmed with hysteria. This state of madness is aptly conveyed through dissonance, antimusical utterances, and musical and textual fixation. In the first stanza, Sara expresses a violent resistance to the unknown act by repeatedly screaming "No" and defiantly shouting "Don't let it be," an antimusical utterance at its best (see strand A for poetic text).

In the third stanza, she is pulled back into the hysteria and desperately seeks to escape reality- "run." This denial is further elaborated in stanza A6's panicked "Go through the trees." Retaining the hysteria from earlier strands, stanza A9 presents Sara so frenzied that she is frozen into indecision: "Go/ Don't go to the house." The theme of hysteria is heightened by the fact that each of the stanzas is stripped of virtually any syntax, cast in the imperative mood and centred on repetitions of simple one-syllable words or short phrases: "no," "run," "go," "go, don't go."

16 Roger Savage, "Le Marteau sans Maître and the Logic of Late Capitalism," Ex Tempore 11, no. 2 (2003): 26.

17 Davies as quoted by Williams, "Madness," 81. For Williams, Maxwell Davies' use of the antimusical in his compositions is directly linked to a modernist critique of the musical establishment. 
Figure 4: Strand A

\begin{tabular}{|l|l||}
\hline Stanza 1 & Stanza 3 \\
No. & run \\
No. & run \\
No. & run \\
No. & run \\
Don't let it be. & run \\
Don't let it be. & run \\
No. & run \\
No. & run \\
No. & run \\
No. & run \\
Don't let it be. & \\
Don't let it be. & \\
Don't let it be. & \\
Don't let it be this way. & \\
Not this way. & \\
Not now. & \\
& \\
Stanza 6 & \\
Go. & Stanza 9 \\
Go. & Go. \\
Go. & go \\
Go. & go \\
Go through the trees. & go to the house \\
Go through the trees. & Don't go to the house \\
Go through the trees & Yes, go to the house \\
to the dark deep & Go to the house \\
dark deep dark & Don't go \\
through the woo-woo-woo-woooods. & to the house house \\
& the house. \\
\hline
\end{tabular}

The musical setting of this strand uses two dissonant musical motives, which I have labelled the Hysteria Chords and the Panic Motive. Besides the fact that these two motives occur in constant alternation (that is, they are repeated innumerable times throughout the strand), each of these motives repeats pitches and/or intervals, further emphasizing obsession and strengthening the overall impression of hysteria the strand conveys. For instance, each of the four stanzas of the strand begins with Sara shouting "No" above the Hysteria Chordsregularly struck chords on the piano-an appropriate assertion for the powerful emotional outburst of hysteria that this strand expresses. The first chord of the two-bar motive is made up of pitches A-E-A in the left hand, against C-F $\#$ G-B in the right hand, and as example 1 shows, occurs four times. Bouchard guarantees the chord's abrasiveness in several ways: the sonority's right-hand chord carries two jarring or dissonant intervals: interval 1 on the chord's inner voices $\mathrm{F} \sharp-\mathrm{G}$; and interval 11 on pitches $\mathrm{C}-\mathrm{B}$ in the outer two voices, struck in the extreme high range of the keyboard at dynamic markings of $s f z$. In the second half of this motive (measure 10), the chord is transposed and partitioned into two dyads-pitch interval 11 and pitch interval 6. The right-hand chord retains the pitch interval 11, transposing it up from $C-B$, to E-D\#, whereas the left hand retains pitch interval 6 , transposed to pitches $D \#$ and A. Finally, the second half of measure 10 also makes use of the same intervallic content of the chord, this time using a transposition that retains pitches $\mathrm{E}$ and $\mathrm{D} \#$ from the first half of the measure, but adding $A \sharp$ and $B$. Apart from the repetition within the Hys- 
teria Chords, the effect of hysteria is heightened by the violence and tension created by the rhythmic setting: the regularly spaced dissonant quarter-note chords are obstructed by snatches of chords with a more spasmodic rhythmic setting - the juxtaposition of a steady rhythm with an agitated one, creating a mimetic representation of Sara's frenzied state. Finally, the chords' oscillation between extreme low, middle, and extreme high registers of the keyboard contributes to the feeling of agitation.

The other prominent motive, the Panic Motive, accompanies Sara's anxious impulse for action as if directing herself: "don't let it be," "go through the trees," "don't go to the house." As example 2 shows, this motive is also structured around a repeated kernel: the descending vocal line E, C, F\#, which recurs twice, only to be slightly altered for the third presentation. Importantly, the overall trajectory of the melodic line is $\mathrm{E}$ to $\mathrm{E} \#$-again underscoring inter-

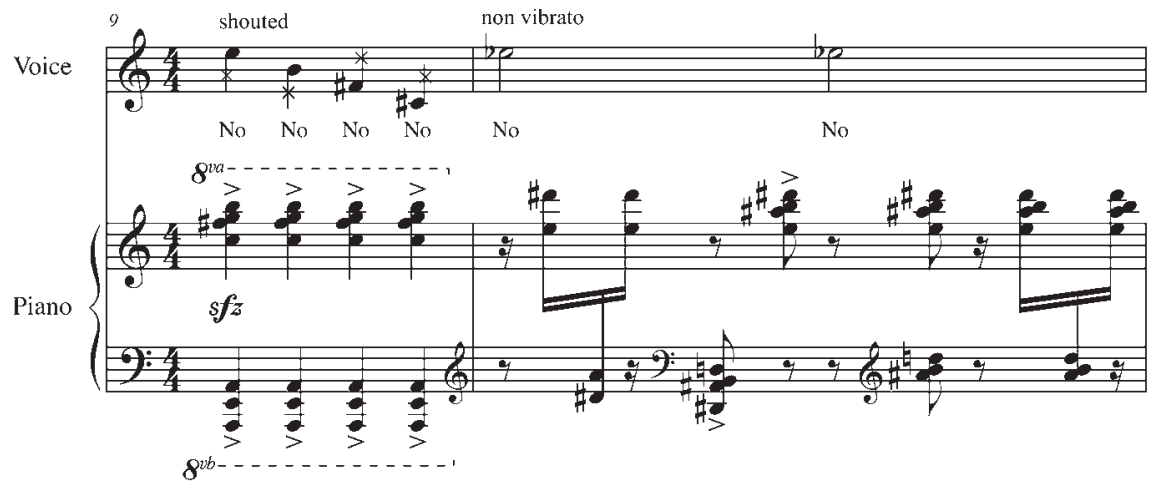

Example 1: Black Burned Wood, stanza 1, Hysteria Chords

val 1. Underneath the vocal line, in a repetitive chordal statement, the piano accompaniment reiterates the three sonorities, E, C, and F\# from the vocal line, adding to them first a B and then on beats three and four, an F and D\#. Besides repeating pitches and intervals of the vocal line in the accompaniment, the piano chords in the first measure retain the Hysteria Chords' pitches $\mathrm{F} \#, \mathrm{~B}$, and $\mathrm{C}$ (from the first chord). The Panic Motive's cross-rhythms of middle-register chords also retain the jarring and dissonant effect of pitch intervals o1, and o6. Finally, the agitation of the Panic Motive is further accented by the short values of the vocal part, whose hurried action seems to set off the syncopated chords in the piano accompaniment.

These two motives make up all of the material for stanzas A1, A6, and A9; only stanza A3 varies slightly by virtue of its use of only the Hysteria Chords, something occasioned by the text, which, rather than having an additional phrase, repeats only the single word "run." The strand thus utilizes a real economy of pitches and motives, helping to affirm Sara's obsessive psychological state. 


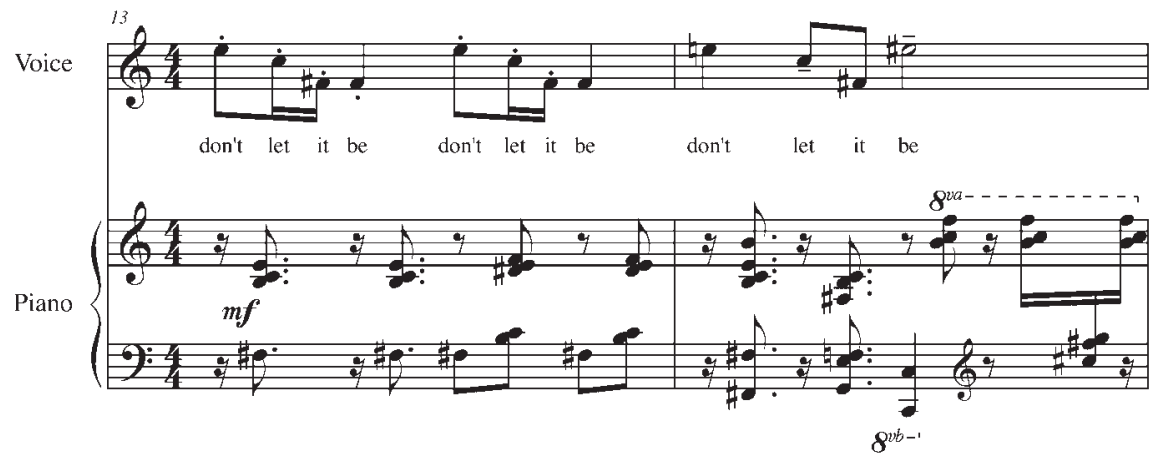

Example 2: Black Burned Wood, stanza 1, Panic Motive

Strand B is thematically centred on Sara's regression to an underdeveloped state of consciousness where she represses the knowledge of her involvement in the unnamed act. The music constructs an aspect of Sara's deranged state less visible in the text: regression to a state of childhood suggested by a haunting recollection of the children's nursery rhyme, "It's Raining, It's Pouring." The poetry suggests Sara's regression with an immature dislike for her name ("her name is Sara ... but she doesn't like it"), her propensity to talk about and to herself ("you didn't do that, did you, Sara?"), and her use of simple phrases in a childish taunting manner ("not so much, not so much, not so much"; see strand B).

Figure 5: $\quad$ Strand B

\begin{tabular}{||l|l|}
\hline Stanza 2 & Stanza 5 \\
Her Name is Sara. & I can't believe that it's true \\
That's what they called her, Sara. & S A R A. \\
But she doesn't like it so much & You didn't do that \\
not so much not so much & did you? \\
but she doesn't like it. & You didn't do that \\
She would rather have been named after a & did you? \\
Saint! & The house won't go to sleep now. \\
& The house won't go to sleep now. \\
& Stanza 11 \\
& Sara . . . \\
& Sara . . . . coming. \\
& .. \\
\hline
\end{tabular}

The repressed act surfaces in veiled ways, creating tension with her feelings of responsibility. In stanza $\mathrm{B}_{2}$, for instance, she projects the subject as another-"her name, that's what they call her." Then, almost in an effort to divert our (or her) attention from the trauma, she changes the subject, "She would rather have been named after a Saint," in a statement that both acknowledges her impurity and imputes her desire for disassociation. The fifth stanza blatantly exposes the act and her denial as she rhetorically asks, "You didn't do that, did you?" Finally, Sara seems to accept responsibility by responding "coming" to the voice that has called her name, the voice itself a sign of the 
repressed act calling her name. But as the musical setting demonstrates, she is not equipped to do so.

Strand B also relies on fragmentation, musical fixation, and dissonance, though here they are treated differently because of the context of the Strand's state of madness. The nursery rhyme used here fine-tunes Sara's regression to a state of childhood at the same time that it acts as an interruption to Sara's temporal frame, implying that her madness results from an act from the past. The children's tune makes its strongest impression at the outset of stanza B2 where it is set in the vocal part; accompanying Sara's puerile tune, the implication of an F major diatonicism, the simple rhythmic structure, and the slower tempo portray the vacillation between the adult/child she experiences. Underneath this children's tune, however, the musical accompaniment points to something rather more sinister. Here, as shown in example 3, is what can be called the Delinquent Rhyme Accompaniment: while the vocal part, the pizzicato violin, and most of the notes in the piano's left-hand accompaniment set up a diatonic musical syntax based in F major, the remaining accompaniment antagonizes the childlike innocence with its steady assertion of dissonance, through a presentation of notes outside the key of $\mathrm{F}$ major. This assertion of dissonance is especially strong against the overarching F major tonic that not only acts as a pedal for the tune, but serves as the "normative" harmonic accompaniment. Only the $\mathrm{B}$ a in the piano's left hand, and the C\#s in the right hand pull away from the tune's tonic key. Circled pitches in Example 3 in the xylophone and piano illustrate non-diatonic pitches. Although these non-diatonic pitches in the accompaniment resemble the octave tremolos outlining the nursery rhyme in the introduction, in this passage they are corrupted, signalling something "off" in Sara's character. A comparison of the nursery rhyme from the introduction and the Delinquent Rhyme Accompaniment (see example 4) shows that the octave boundaries are extended outside the F major diatonicism and that the rhythm is fragmented. Octave gestures from the original tune are retained, skewed, or fragmented. In the example, line B uses large note heads to show the melody of the nursery rhyme, while lines D, E, and F use stemmed pitches to illustrate the tune's skeleton. Because of the disjuncture between the diatonic nursery rhyme and the corrupted pitches and rhythm of the Delinquent Rhyme Accompaniment, an aura of the sinister pervades the passage. Another good example of how Bouchard "corrupts" the tune's accompaniment can be seen in measure 45 (see example 5) against the violin's pizzicato presentation of the nursery rhyme and Sara's angry remarks. In this example, the accompaniment's texture, rhythmic treatment, and overall skeleton are retained in both the piano and xylophone, though the chromatic notes persistently distort the octave boundaries. Present throughout strand B's stanzas 2 and 5, and further fragmented in stanza 11, the juxtaposition of the nursery tune against the Delinquent Rhyme Accompaniment serves as a reminder of Sara's corrupted state.

In stanza $B_{2}$, the nursery tune also deviates from its own system of logic, thereby confirming the state of derangement disclosed in the syntactical split between the images associated with the nursery rhyme and those created by 

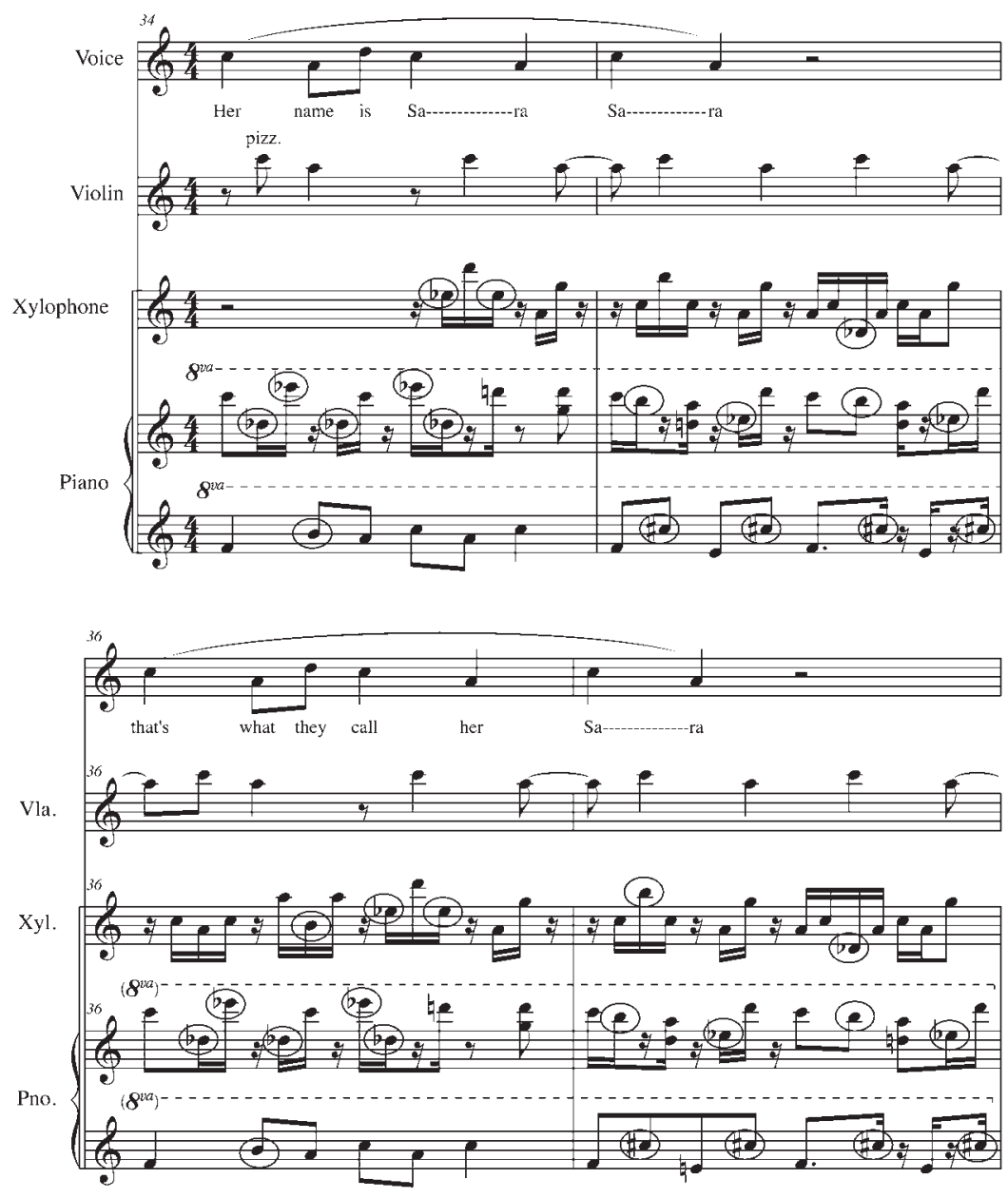

Circled notes are those outside the $F$ major diatonic

Example 3: Black Burned Wood, stanza 2, nursery rhyme with Delinquent Rhyme Accompaniment

the Delinquent Rhyme Accompaniment. This deviance is caused by the object of Sara's repression intruding into her vocal line in the form of a $\mathrm{D}^{b}-\mathrm{C}$ dyad, the same interval class (o1) that permeated the musical fixation of the Hysteria Chords. First, Sara uses only the first five notes of the original nursery rhyme, a fragment demonstrating that she is too demented to provide its logical completion. This fragmented version becomes normalized by its restatement and repetition so that when the third statement begins, the listener expects it to conform to its earlier presentation. Example 6, measures 39-42, begins with the third statement of the tune and shows how, when in measure 39 the C-A dyad in the first two statements is unexpectedly replaced by $D^{b}-C$, our suspicions of Sara's derangement are confirmed. Besides not fulfilling the pitch 
Introduction: Nursery Rhyme

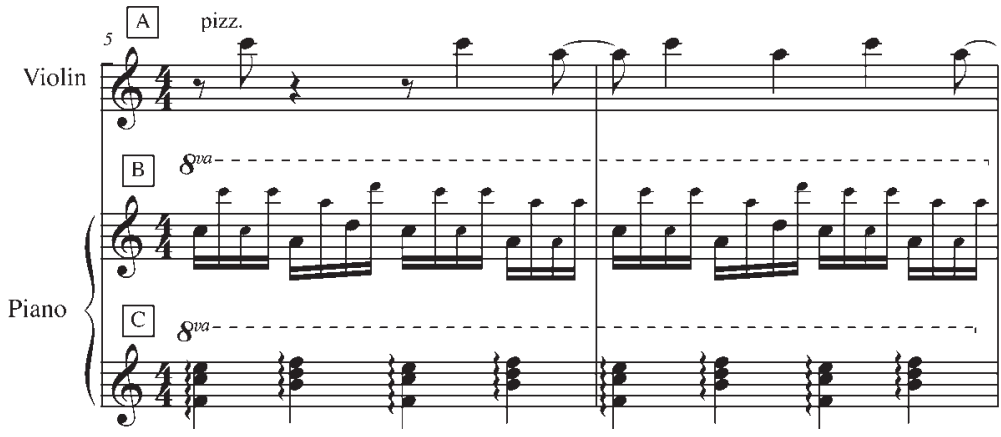

Delinquent Rhyme Accompaniment:

Piano m.34 DRA
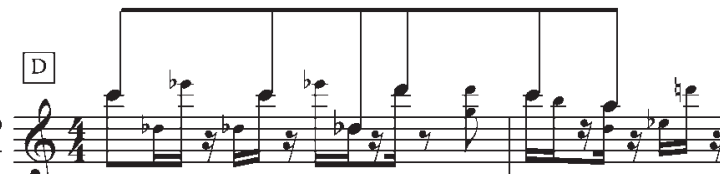

Normative

Accompaniment:

(rhythmic reduction)
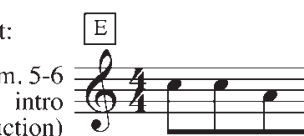

Delinquent Rhyme

Accompaniment:

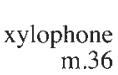

DRA

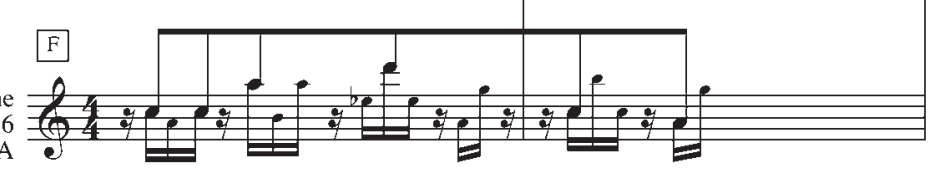

Example 4: Black Burned Wood, comparison of nursery rhyme from introduction and Delinquent Rhyme Accompaniment from stanza 2

expectations, the $\mathrm{D}^{b}-\mathrm{C}$ calls attention to itself by the registral displacement: the low growl betrays an element of danger. The dyad thus signals the obsessive intrusion of the unnamed act from strand A. The state of derangement presented in strand B is thus asserted in a creepy juxtaposition of disparate images-the nursery rhyme set against the Delinquent Rhyme Accompaniment while Sara's ingenuous singing is impulsively and unwittingly overtaken by low, threatening snarls, that Williams would undoubtedly call antimusical. These low $\mathrm{D}^{b}-\mathrm{C}$ snarls intrude in a similar fashion into Sara's strained vocal line in stanza 5 as well.

Stanzas 2, 5, and 11 of strand B are thus musically unified by the use of the nursery rhyme, the Delinquent Rhyme Accompaniment, and a strategy of setting up and then rejecting expectations. One further example of this last 


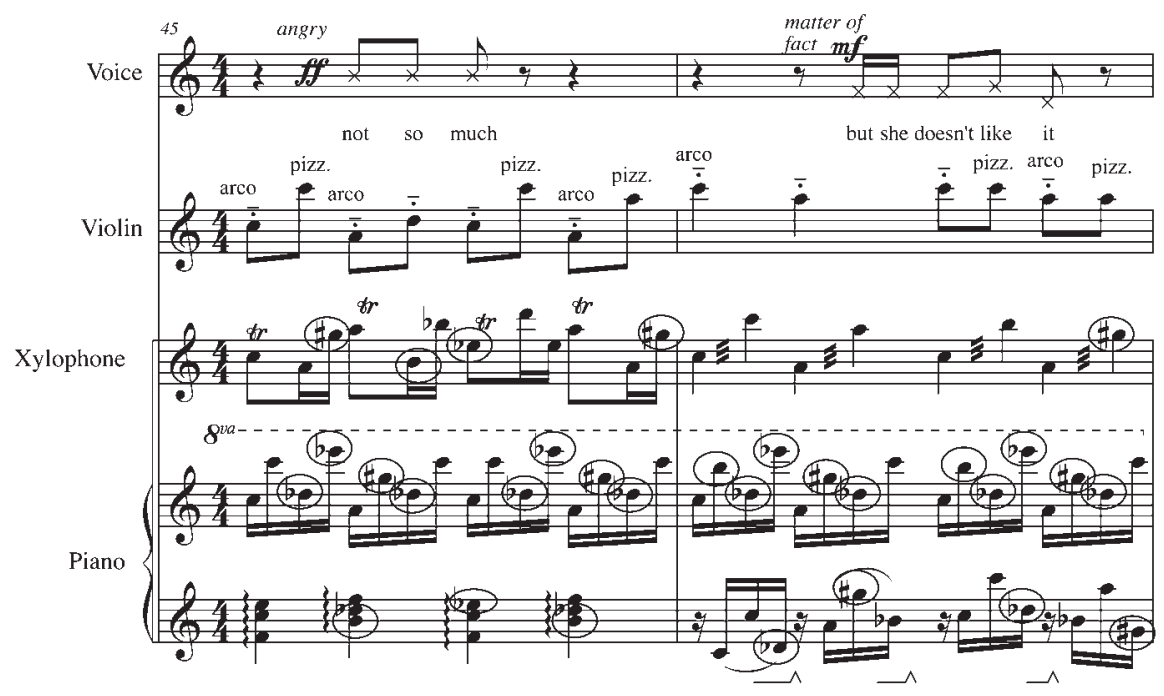

Example 5: Black Burned Wood, stanza 2, nursery rhyme with a later section of the Delinquent Rhyme Accompaniment

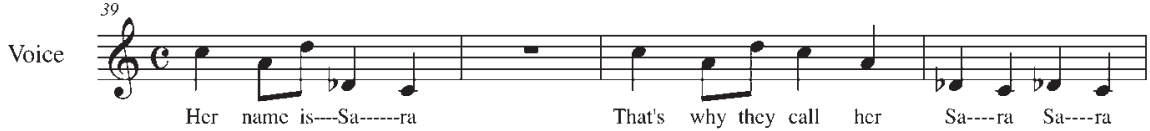

Example 6: Black Burned Wood, stanza 2, unexpected entries of the D flat C dyad

process connects the last parts of stanzas $\mathrm{B}_{2}$ and $\mathrm{B}_{5}$ where, in contrast to the fragmented vocal lines, Sara expands her range in an excessively long sentence almost achieving a linear, coherent musical line (as can be seen in example 7 , measures 48-51). The stark contrast between the shorter fragments and the longer line narrates Sara's attempt to break out of her confined state. As if expressing the point of articulation between her rational and deranged selves, halfway through the sentence Sara slows down and inverts the falling $\mathrm{D}^{b}-\mathrm{C}$ semitone dyad she began with, to a rising $D^{b}-C$. The exaggerated nature of the second part of the line in particular and the literary content signal her continued delusions and flaunt her inability to break free from her mentally confined state. The child-like exclamations of "oh" (measure 51) set over chords resembling the hysteria chords from Strand A confirm this.

The third emotional state of madness, strand C, places Sara in a schizophrenic conflict between acknowledging and denying what she has done. The compositional techniques of musical fixation and dissonance are again cast differently to reflect the strand's thematic content. Acknowledging the event causes Sara to be hysterical, whereas denying it causes her to regress. Sara's acknowledgement and denial are channelled into conscious and unconscious states and explored vis-à-vis the division of her self into mind and body. 


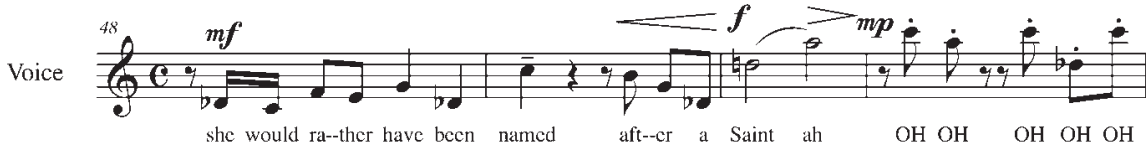

Example 7: Black Burned Wood, stanza 2, Sara’s longer line

Figure 6: Strand C

\begin{tabular}{|c|c|}
\hline $\begin{array}{l}\text { Stanza } 8 \\
\text { And the sun is shining, } \\
\text { shining, } \\
\text { shining, } \\
\text { setting, } \\
\text { setting, } \\
\text { shining, } \\
\text { shining ... }\end{array}$ & $\begin{array}{l}\text { Stanza } 7 \\
\text { When I go to the forest I don't do } \\
\text { the same things I do at the house, } \\
\text { not there, } \\
\text { not like that place } \\
\text { not at the house, } \\
\text { the house... } \\
\text { When I'm in the forest I drink from } \\
\text { the streams } \\
\text { like the deer. } \\
\text { When I'm there I don't make a } \\
\text { sound } \\
\text { I listen ... } \\
\text { and I hear... } \\
\text { everything. } \\
\text { I can hear them talking through my } \\
\text { body } \\
\text { in the forest. } \\
\text { Stanza } 10 \\
\text { Windows... } \\
\text { Windows ... } \\
\text { The sun shining on the windows is } \\
\text { sinking } \\
\text { and soon it will be dark inside } \\
\text { but I have left the light on } \\
\text { in the kitchen } \\
\text { and the bathroom and the hall and } \\
\text { upstairs } \\
\text { where mama } \\
\text { and dad } \\
\text { sleep }\end{array}$ \\
\hline
\end{tabular}

In the poem, the "house" might be interpreted as a metaphor for her mind, a constructed place where thoughts are constituted on a conscious level according to societal, outside influences; thus, the house mediates her natural impulses. She yearns for the "forest" - the body—-the site for her emotional and unconscious impulses where her natural instincts may dominate. One sign of this mind/body split appears in stanza $\mathrm{C}_{7}$, where she tells us she behaves differently at the house. This mediation is also responsible for her paranoia, where in stanza $\mathrm{C}_{4}$ she constructs the image of someone calling her, to which she responds that she is on route to "Black Burned Wood." But even in the forest, paranoia intrudes: she can hear them "talking through her body." In stanza 8 , which I include here as C-B8 since it shares features of both strands, Sara digresses to an almost unconscious state in which her hallucination takes on the paradoxical form of a sun, shining and setting at one and the same time. In stanza C1o, Sara is compelled to explain what she did, but her condition makes 
it difficult for her to tell us exactly. At the same time, she seems aware of the conflict, and how her actions will affect her ("soon it will be dark inside").

In this strand, Bouchard communicates Sara's state of conflict through the use of angular and disjointed vocal lines that exaggerate or altogether deny conventional linear phrase contours. In stanza $\mathrm{C}_{4}$, the vocal part plays with the listener's expectations by offering to follow the conventional gestures of rising motion for questions and downward motions for answers, but each of the gestures is exaggerated. Each repetition of the question "are you calling?" is set to pitches that rise as if imitating the natural rising inflection of the voice, though the ascent is extreme and disjunct. As one might expect, the answer "she can't come now" is figured in a descending overall line, here sharp and abrupt to signal instability (see example 8). The constant up and down motion of the vocal line in stanza $\mathrm{C}_{4}$ also recurs in stanzas $\mathrm{C}_{7}, \mathrm{C}-\mathrm{B} 8$ and $\mathrm{C}_{10}$, each recurrence set to wider intervals, thereby increasing the line's angularity. The initial repetition and the constant up-and-down motion, both forms of musical fixation, express a lack of agency on Sara's part that I will describe with the imagery of a ricochet. An example of this ricochet motion can be heard in stanza $\mathrm{C}_{7}$, measures 138-41 shown in example 9, when a recurring motive involves a contrast of a low $\mathrm{F}_{4}$ with the higher-register pitches $\mathrm{E}^{\mathrm{b}} / \mathrm{E}$,, $\mathrm{C}$, and D. Many of the following motives retain the shape and gesture but as the stanza unfolds, the pitches available to the voice are pared down so that, for instance in measures 159, and 164 shown in example 10, the up/down gesture and characteristic interval shapes are preserved but the notes are pared down to a low $\mathrm{F}_{4}$ to $\mathrm{E}^{b_{5}}$ and $\mathrm{F}_{4} 4$ to $\mathrm{E}_{5}$. Here, the two fixed registers, low (as in $\mathrm{F}$ and $\mathrm{F} \#$ ) and high (as in $\mathrm{E}^{b}$ and $\mathrm{E}$ ), ricochet back and forth between the two fixed polarities of Sara's mind. The lack of linearity, the expression of disjunct melodic systems, and the fact that the instruments are restricted to small motivic cells void of tonal harmonic structure confirm overwrought images from the world of atonal expressionism.

How the three strands interact with one another in terms of relationships made within the strands, and relationships made between the strands is also instrumental in narrating Sara's madness. The fact that the ends of these musical strands often fragment or disintegrate unexpectedly highlights the volatility suggested by the extreme mood swings. As the piece unfolds, and as we hear stanzas of different musical strands in succession, we are able to hear relationships and draw connections between stanzas of different strands. For example, the first time a reference to the nursery rhyme "It's Raining, It's Pouring" is made in the introduction (shown in example 4), Bouchard sets it in a fairly straightforward manner, seeming to imply a state of childhood. In its simple rhythmic and metric structure and its expression of diatonicism, this tune sits in stark contrast to the outbursts of Hysteria Chords and Panic Motives that permeate the following stanza, stanza A1. When, after this expression of hysteria, another version of the nursery rhyme returns in stanza B2, this time accompanied by the Delinquent Rhyme Accompaniment (which denies the tonal syntax of the tune, and invokes a relation to the introduction), we understand the delinquency as somehow linked to, even induced by, the hysteria. If 

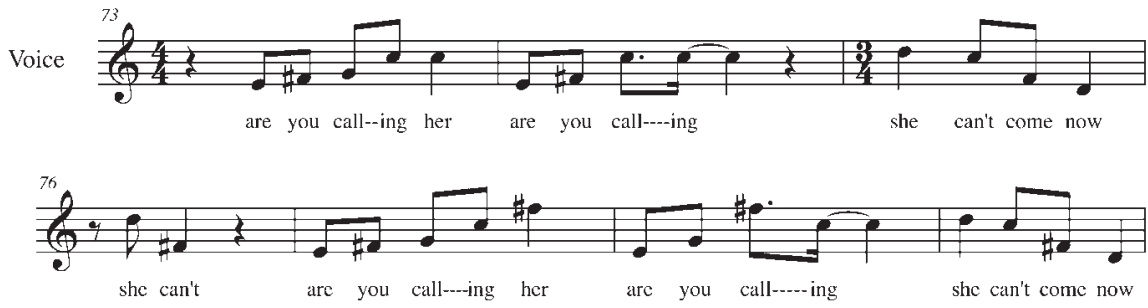

Example 8: Black Burned Wood, stanza 3, exaggerated questions and answers

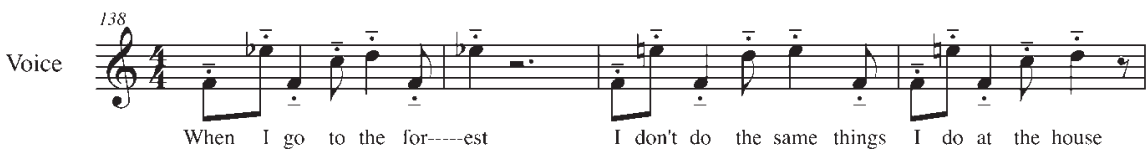

Example 9: Black Burned Wood, stanza 7, angular melodic lines: ricochet style

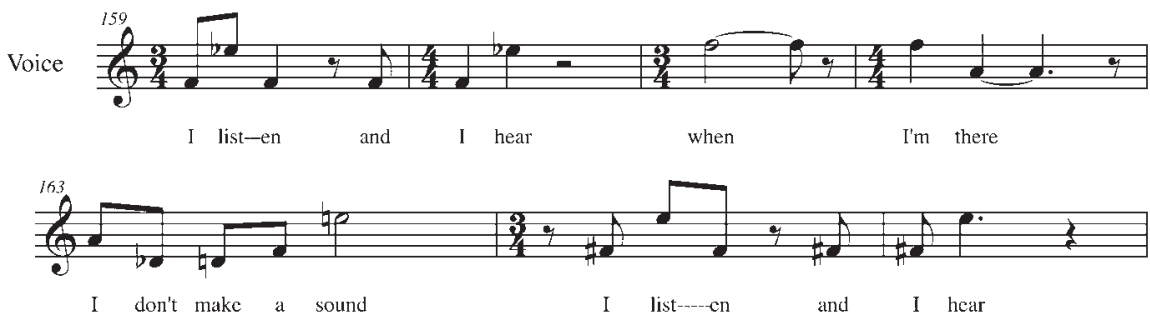

Example 10: Black Burned Wood, stanza 7, Ricochet Motive

that's not enough, at the end of this stanza (2), a snippet of the hysteria chords from stanza A1 intrudes as if to confirm the connection.

As in the above instance where a fraction of a motive from an earlier strand finds its way into another stanza, demanding to be heard in relation to it, a prominent motive from strand $\mathrm{B}$ slips into $\mathrm{C} 7$, thereby connecting the emotional expression of this stanza to the earlier $\mathrm{B}_{2}$ and $\mathrm{B}_{5}$. In stanza $\mathrm{C}_{7}$, sharp, angular melodies that soar up from a low $\mathrm{F}_{4}$ are frustrated by short, clipped two-note phrases, the interruptions often striking a $D^{b} 4$ as example 11 shows. The register and setting of these low $\mathrm{D}^{b}$ s recall the $\mathrm{D}^{b}$-C dyads that arose as the musically fixated object of Sara's repression in the vocal lines of stanzas B2 and B5; the earlier dyads are shown in example 5: their suggested presence here in strand C seems to confirm the fact that Sara is haunted by these events (and will continue to be).

The cyclical pattern of the work and the defining characteristics of the stanzas' musical sound worlds are well established by the beginning of stanza C-B8, so that when this stanza begins it seems out of place. The pattern established thus far suggests that stanza 8 belongs with strand B's members 2 and 5 . However, stanza 8 's musical material is different, and closer to the musical material of stanzas in 

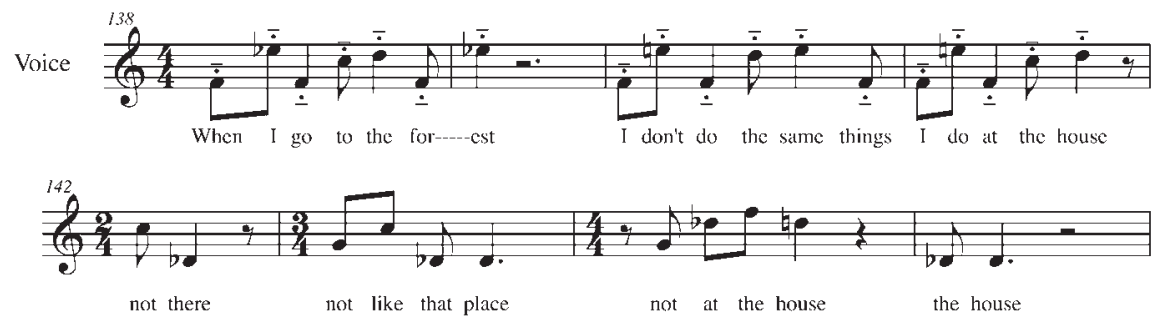

Example 11: Black Burned Wood, stanza 7, D flat interruptions at "the house"

group C: Sara's vocal line drops all references to the nursery rhyme while her accompaniment drops its Delinquent Rhyme Accompaniment, as if her mental anguish has erased both from her memory. The sound world of stanza C-B8 is also closer to strand $\mathrm{C}$ in its sparser texture and chordal accompaniment. However, linking stanza C-B8 to strand B is possible on the basis that the rhythmic regularity is kept and the two-note motive that is developed in this stanza derives from the Dflat-C dyad from $\mathrm{B}_{2}$ and $\mathrm{B}_{5}$. In this case, however, instead of occurring as a descending half step, the dyad appears to be corrupted by the ricochet movement from strand $\mathrm{C}$, in its constant up and down, almost predetermined motion. Indeed, a fragment of the Ricochet Motive from stanza $\mathrm{C}_{7}$ remains in stanza C-B8, transforming its musical world. The relationship between C7's Ricochet Motive and the up-and-down movement in the vocal line of stanza C-B8 is also cemented by the fact that the final note of the last sung phrase of $\mathrm{C}_{7}$ (shown in measure 165 of example 10) and the first note of the beginning phrase of C-B8 share pitch E5, as example 12, measures 171-8 shows. Sara retains the up/down gestures until, finally, a $\mathrm{C} \#$ emerges as the final solution. Here, the fixity of register and pitch $\mathrm{C} \#$ recall the low growls of $\mathrm{D}^{b}-\mathrm{C}$, which intruded into both stanzas 2 and 5 , except here the $\mathrm{D}^{\mathrm{b}} / \mathrm{C} \#$ follows a different chromatic pitch, $\mathrm{D}$. This breakdown between the two upto-now-distinguishable sound worlds of $\mathrm{C}$ and $\mathrm{B}$, as suggested by the shared use of the $\mathrm{D}^{b_{s}}$ and Ricochet Motive, is the first clear sign of Sara's disintegration and sets off a process of fragmentation that ultimately consumes the structure of the work. In stanza C7, Sara's conflicted mind finds refuge in the forest ("When I go to the forest ... I drink from the streams like a deer") but is eventually unsuccessful in warding off paranoia ("I can hear them talking through my body in the forest"). Stanza C-B8 begins with "and," linking the two stanzas lexically and confirming that we are still in the same schizophrenic emotional state, in C-B8, involving the contradictory images of a sun shining and setting at the same time.

The breakdown intimated by the collapsing of the two musical sound worlds of strands C and B is supported by hints of hysteria in the form of percussive sounds that have introduced the Hysteria Chords in the past. These percussive sounds intrude into parts of stanza C-B8 until finally, at the end of the stanza in measures 179 and 180, the Hysteria Chords succeed in penetrating it, bringing Sara right back to the highly repetitive and restricted musical language of strand A that constrains her. That Sara's hysterical state is the source of her antagonism and fuel for her destruction is proved insofar as its musical world remains intact. 
The hysteria continues its offensive and Sara's condition worsens. In stanza C10, after the bout of hysteria and conflict about whether or not to go to the house as expressed in stanza A9, Sara relapses into the same angular and overwrought melodies from stanza $\mathrm{C}_{7}$, unable, however, to match their earlier length and variety. Most of the phrases begin on the same pitch-F-a symbol of the circularity of Sara's mental state since each drive toward an escape is thwarted: as example 13 demonstrates, Sara is fated to begin at the same place each time. The pitch F5 also highlights an alliteration of "w" sounds_-"when," "windows," and "where" in stanzas $\mathrm{C}_{7}$ and $\mathrm{C}_{10}$, connecting the phrases musically but aptly revealing that there is no lexical or logical reason for this connection.

In stanza C10, we gradually begin to understand the reasons for Sara's violent reactions to the "house," both in the text and in the music where $\mathrm{D}^{\text {bs }}$ often accompany mention of it ("there," "that place," "the house," seen in example 10). Where earlier intrusions of the $\mathrm{D}^{b}$ occurred with a $\mathrm{C}$, here the dyad is fragmented with only the $\mathrm{D}^{b}$ remaining, a final sign of her disorientation. Sara suggests that she is about to lose everything: "the sun shining on the windows is sinking and soon it will be dark inside." The house surfaces as the site of her crime and she confesses to having done something there, projected as "I have left the light on ... where Mama and Dad sleep." But deranged and confused, Sara speaks in metaphor: "I have left the light on" appears to be a confession of arson. We begin to see that her crime follows her into the forest, her site of refuge: though she wanted to escape to the woods, she has inadvertently found herself at black burned wood (stanza 4), presumably the site of a house fire.

Finally, in the last stanza, B11, the driving force behind Sara's neurotic state, her unnamed crime, forces her into a corner. She is so overwrought she cannot

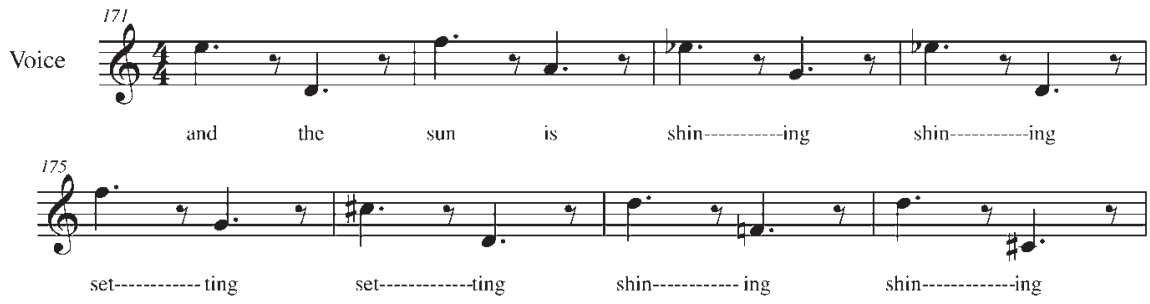

Example 12: Black Burned Wood, stanza 8, D flat corrupted by Ricochet Motive

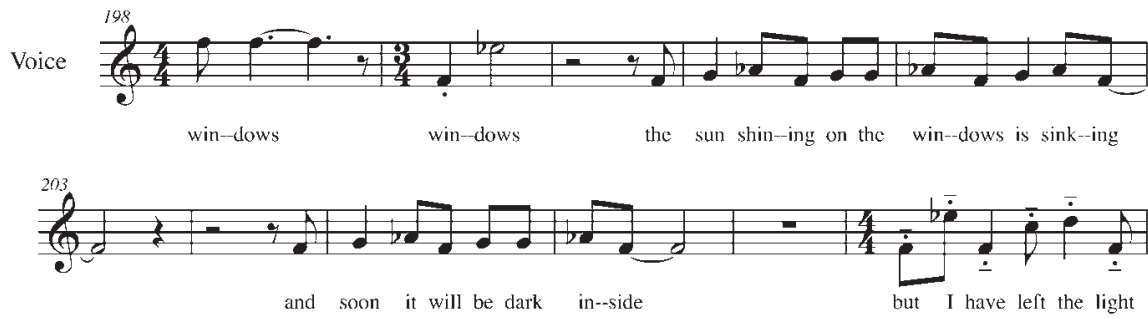

Example 13: Black Burned Wood, stanza 10, circularity, beginning and ending on F 
even concentrate enough to remember the nursery rhyme, singing, as example 14 shows, only a fragment-two pitches over her name. Her dissociation from events is suggested by the fact that the two notes she sings are displaced and transposed to $\mathrm{C}$ major, though the violin accompaniment is in an unchanged $\mathrm{F}$ major. The delinquency of the xylophone accompaniment and its increased speed further emphasize the breakdown. And her response is to go to the pitch that destiny has pronounced for her-two protracted $\mathrm{F}_{4}$ pitches accompany her resignation ("coming"). But eerily, within the wash of $\mathrm{C}$ major suggested by the vocal echoes of "Sara," the F looms menacingly out of place.

With its musical images of hysteria, paranoia, and schizophrenia, Linda Bouchard's Black Burned Wood easily casts John O'Keefe's poem Sara Songs into the discursive tradition of madwomen. Moreover, the association of infantilism with Sara's demise further demarcates this discursive tradition and distinguishes evocations of men's and women's madness in this and other works. The strength of Bouchard's musical representation of Sara's mental condition lies in its use of musical material that has strong associations with musical representations of madwomen: non-linearity, fragmentation, musical fixation, and dissonance. Yet how this musical material is presented in each strand of Sara's madness is evocative of the different psychological states of madness the protagonist experiences-the violent screams and shouts, against dissonance and musical fixation suggest hysteria; the nursery rhyme against a non-diatonic accompani-
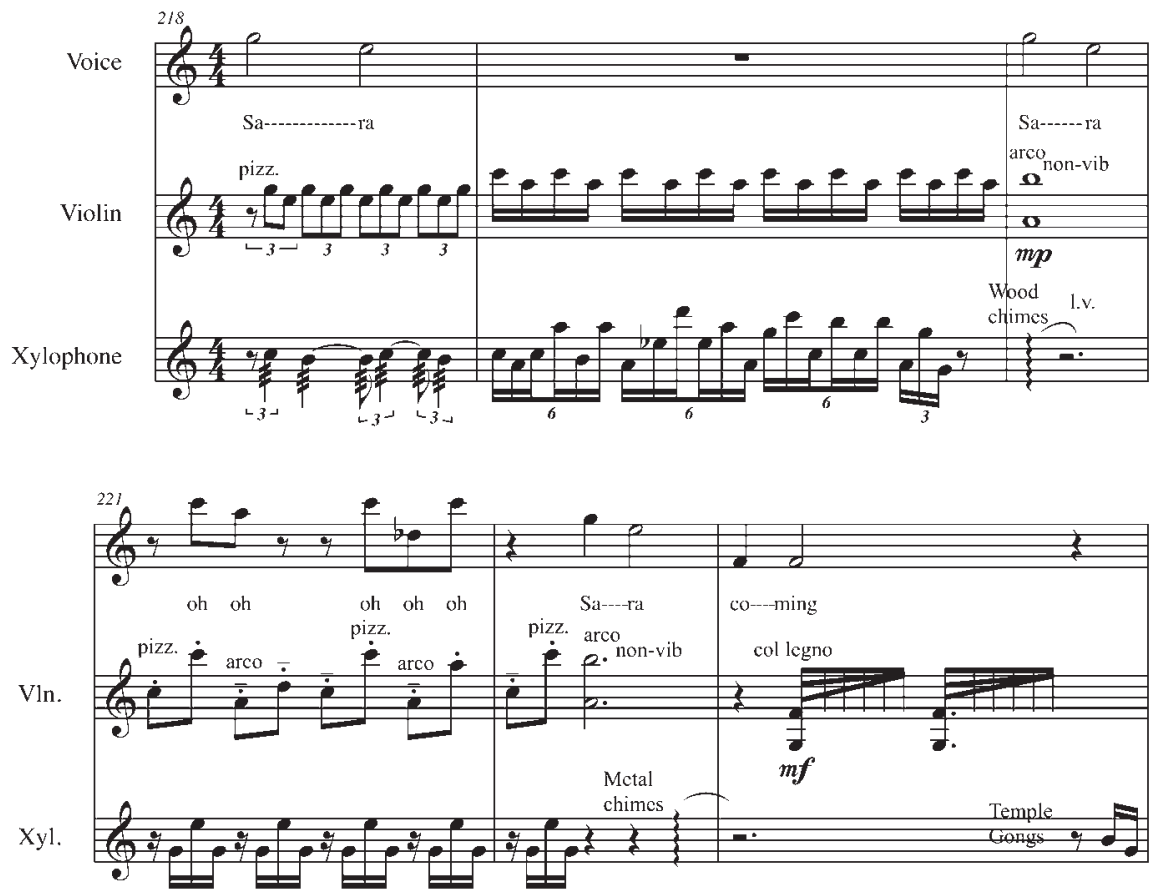

Example 14: Black Burned Wood, Stanza 11, Fragments of Nursery Rhyme transposed to C with delinquent accompaniment 
ment, a regression to a childlike state; the angular and exaggerated vocal writing, an overwrought condition reminiscent of paranoia and schizophrenia. As well, a musical setting that ensures each state of madness be cycled and recycled establishes a loop structure where Sara re-experiences the same three psychological states. The nature of this structure secures the constant alternation of sound worlds, as if invoking stream of consciousness, a well-known feature of earlier musical and textual representations of madwomen. Across this structure, Bouchard carefully inserts musical ideas that signal obsession and intrusion so that the listener is gradually able to hear the source of Sara's breakdown and piece together the relationship between the psychological states she experiences. Finally, the eventual thinning out of Sara's compositional materials forces her to take the only path available to her: resignation.

\title{
ACKNOWLeDgement
}

I am grateful to Judy Lochhead, Lloyd Whitesell, and the two anonymous readers for their detailed comments on earlier drafts. I would also like to thank Kevin Swinden for his help with the musical examples.

\begin{abstract}
With its images of paranoia, anger, resignation, and infantilism, Linda Bouchard's Black Burned Wood may easily be aligned with musical representations of madwomen. The text, a cycle of eleven poems collected under the title "Sara Songs" takes the form of a rambling monologue in which Sara struggles to come to grips with her role in an unspecified but horrible act. Although the syntactic structure and verbal content of the poems place Sara in a state of derangement, it is the musical setting that is responsible for the instantaneous and overwhelmingly raw portrayal of Sara's madness. This paper explores the use of fragmentation, non-linearity, musical fixation, and dissonance to musically represent Sara's madness.
\end{abstract}

\section{RÉSUMÉ}

Par ses images de paranoïa, de colère, de sacrifice et d'infantilisme, Black Burned Wood de Linda Bouchard peut facilement s'inscrire dans le sillage des représentations musicales de la folie féminine. Le livret, un cycle de 11 poèmes réunis sous le titre de "Sara Songs », prend la forme d'un monologue décousu dans lequel le personnage de Sara peine à accepter son rôle dans un acte incertain mais horrible. Bien que la structure syntaxique et le phrasé des poèmes montrent le déséquilibre mental de Sara, c'est la musique qui est responsable de la description instantanée et incroyablement à vif de sa folie. Cet article explore l'utilisation de la fragmentation, de la non-linéarité, de la fixation musicale et de la dissonance pour représenter musicalement la folie de Sara. 